\title{
Kinetic study of the gas-phase reaction of atomic chlorine with a series of aldehydes
}

\author{
D. Rodríguez ${ }^{1}$, A. Rodríguez ${ }^{1}$, A. Notario $^{2}$, A. Aranda ${ }^{3}$, Y. Díaz-de-Mera ${ }^{3}$, and E. Martínez ${ }^{3}$ \\ ${ }^{1}$ Facultad de CC Medio Ambiente, Universidad de Castilla La Mancha, Avenida Carlos III, s/n, 45071 Toledo, Spain \\ ${ }^{2}$ Instituto de Tecnologías Química y Medioambiental (ITQUIMA), Universidad de Castilla La Mancha, Avenida Camilo José \\ Cela, s/n, 13071 - Ciudad Real, Spain \\ ${ }^{3}$ Facultad de CC Químicas, Universidad de Castilla La Mancha, Avenida Camilo José Cela, no. 10, 13071 - Ciudad Real, \\ Spain
}

Received: 6 April 2005 - Published in Atmos. Chem. Phys. Discuss.: 22 July 2005

Revised: 16 November 2005 - Accepted: 16 November 2005 - Published: 20 December 2005

\begin{abstract}
The reactions of $\mathrm{Cl}$ atoms with a series of unsaturated aldehydes have been investigated for the first time using a relative method. In order to obtain additional information for a qualitative structure versus reactivity discussion, we have also determined the rate coefficients for the reactions of atomic chlorine with their respective saturated aldehydes. These relative measurements were performed at room temperature and atmospheric pressure of air and $\mathrm{N}_{2}$, by using ethane, propene and 1-butene as reference compounds. The weighted average relative rate constants obtained, $\mathrm{k}_{C l} \pm 2 \sigma$ (in units of $\mathrm{cm}^{3}$ molecule ${ }^{-1} \mathrm{~s}^{-1}$ ) were: trans-2-pentenal $(1.31 \pm 0.19) \times 10^{-10}$; trans-2-hexenal $(1.92 \pm 0.22) \times 10^{-10}$; trans-2-heptenal $(2.40 \pm 0.29) \times 10^{-10} ; \quad$ n-pentanal $(2.56 \pm 0.27) \times 10^{-10} ; \quad$ n-hexanal $(2.88 \pm 0.37) \times 10^{-10}$; n-heptanal $(3.00 \pm 0.34) \times 10^{-10}$.

Finally, results and atmospheric implications are discussed and compared with the reactivity with $\mathrm{OH}$ and $\mathrm{NO}_{3}$ radicals.
\end{abstract}

\section{Introduction}

Large quantities of aldehydes are directly emitted into the atmosphere from biogenic and anthropogenic sources and are also produced in the atmosphere as intermediates in the photooxidation of volatile organic compounds (Papagni et al., 2000). Recently, several saturated aliphatic aldehydes have been identified and quantified in on-road vehicle emissions (Grosjean et al., 2001). Moreover, higher aldehydes have been observed in ambient air in urban and rural areas due to the emissions from vegetation (Prates et al., 1998). In relation to the tropospheric sinks, carbonyl compounds generally show a weak absorption spectrum in the region $220-370 \mathrm{~nm}$ resulting from a dipole forbidden $\mathrm{n}-\pi^{*}$ transition which may

Correspondence to: A. Notario

(alberto.notario@uclm.es) lead to photo-dissociation, generating organic free radicals in the lower troposphere. The primary reaction of these organic compounds can occur with many atmospheric oxidants such as $\mathrm{OH}$ (in the day-time), $\mathrm{NO}_{3}$ (in the night-time), $\mathrm{O}_{3}$ (mainly with unsaturated compounds) and $\mathrm{Cl}$ (in the marine environment and coastal areas). In this sense, the reactions with $\mathrm{Cl}$ atoms have been postulated to be an additional and significant removal process of VOCs in marine troposphere, where the concentration of $\mathrm{Cl}$ precursor species from the reactions of $\mathrm{NaCl}$ in sea salt particles has been reported to be high (Spicer et al., 1998), and it may significantly contribute to the formation of ozone and other components of the photochemical smog in these areas. Assuming a peak $\mathrm{Cl}$ concen-

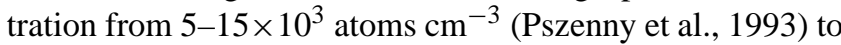
$10^{4}-10^{5}$ atoms $\mathrm{cm}^{-3}$ (Wingenter et al., 1996; Singh et al., 1996) the effect on the removal of aldehydes can be relevant. Therefore, more information about $\mathrm{Cl}$-initiated oxidation processes is needed to assess the impact of VOCs on air quality.

In this work, we report a kinetic study at room temperature and high pressure conditions of the reactions between $\mathrm{Cl}$ and a series of aldehydes which have not been studied previously, excepting n-pentanal, n-hexanal and n-heptanal. The obtained results are compared with those corresponding to the reactions with $\mathrm{OH}$ and $\mathrm{NO}_{3}$ radical. In this sense, the study of the reactions of trans-2-pentenal trans-2-hexenal, trans-2heptenal, n-pentanal, n-hexanal, n-heptanal with $\mathrm{OH}$ radical has been carried out recently by Albaladejo et al. (2002) by means of PLP/LIF technique at room temperature and as a function of the total pressure. Cabañas et al. (2001a, b) also studied the temperature dependence of the reaction of these saturated and unsaturated aldehydes with $\mathrm{NO}_{3}$ using a fastflow discharge system with LIF detection. The relative rate of these three reactions may define the global distribution of products from the atmospheric oxidation of aldehydes under local conditions.

(C) 2005 Author(s). This work is licensed under a Creative Commons License. 
Table 1. Summary of relative rate measurements for aldehydes at room temperature and 1 atm pressure of $\mathrm{N}_{2}$ or air, and the corresponding absolute value.

\begin{tabular}{|c|c|c|c|c|c|c|c|}
\hline Aldehyde & $\begin{array}{c}\text { [Ald.]10 } \\
\left(\text { molecule } \mathrm{cm}^{-3} \text { ) }\right.\end{array}$ & Reference & $\begin{array}{c}{[\text { Ref. }] 10^{15}} \\
\left(\text { molecule } \mathrm{cm}^{-3} \text { ) }\right.\end{array}$ & $\begin{array}{l}\text { Diluent gas } \\
\text { (No. of runs) }\end{array}$ & $\begin{array}{c}{\left[\mathrm{Cl}_{2}\right] 10^{15}} \\
\left(\text { molecule } \mathrm{cm}^{-3}\right)\end{array}$ & $\mathrm{k}_{\mathrm{ald}} / \mathrm{k}_{\mathrm{ref}}$ & 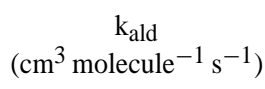 \\
\hline \multirow[t]{3}{*}{ Pentanal } & $1.9-3.0$ & Ethane & $1.4-2.7$ & $\mathrm{~N}_{2}(2)$ Air (2) & $3.0-4.5$ & 4.46 & $2.61 \times 10^{-10}$ \\
\hline & $1.9-2.9$ & Propene & $1.9-2.9$ & $\begin{array}{c}\mathrm{N}_{2}(3) \\
\text { Air }(3)\end{array}$ & $3.0-4.5$ & 1.03 & $2.37 \times 10^{-10}$ \\
\hline & $1.9-3.5$ & 1-Butene & $1.9-3.5$ & $\begin{array}{l}\mathrm{N}_{2}(2) \\
\text { Air (3) }\end{array}$ & $3.0-4.5$ & 0.90 & $\begin{array}{c}2.69 \times 10^{-10} \\
(\mathbf{2 . 5 6} \pm \mathbf{0 . 2 7}) \times \mathbf{1 0}^{-10}\end{array}$ \\
\hline \multirow[t]{3}{*}{ Hexanal } & $1.6-3.2$ & Ethane & $1.4-3.0$ & $\begin{array}{l}\mathrm{N}_{2}(2) \\
\text { Air (2) }\end{array}$ & $3.0-5.0$ & 4.65 & $2.72 \times 10^{-10}$ \\
\hline & $1.6-3.5$ & Propene & $1.6-3.5$ & $\begin{array}{l}\mathrm{N}_{2}(3) \\
\text { Air }(2)\end{array}$ & $3.4-5.0$ & 1.21 & $2.79 \times 10^{-10}$ \\
\hline & $1.8-3.5$ & 1-Butene & $1.6-3.5$ & $\begin{array}{l}\mathrm{N}_{2}(2) \\
\text { Air }(2)\end{array}$ & $3.0-4.5$ & 1.05 & $\begin{array}{c}3.14 \times 10^{-10} \\
(\mathbf{2 . 8 8} \pm \mathbf{0 . 3 7}) \times \mathbf{1 0}^{-10}\end{array}$ \\
\hline \multirow[t]{3}{*}{ Heptanal } & $1.5-3.0$ & Ethane & $1.2-2.7$ & $\begin{array}{l}\mathrm{N}_{2}(2) \\
\text { Air (3) }\end{array}$ & $2.8-4.5$ & 5.00 & $2.92 \times 10^{-10}$ \\
\hline & $1.6-3.0$ & Propene & $2.3-3.0$ & $\begin{array}{l}\mathrm{N}_{2}(2) \\
\text { Air }(2)\end{array}$ & $3.0-4.5$ & 1.31 & $3.03 \times 10^{-10}$ \\
\hline & $1.6-3.0$ & 1-Butene & $2.3-3.0$ & $\begin{array}{l}\mathrm{N}_{2}(3) \\
\text { Air (2) }\end{array}$ & $3.0-4.2$ & 1.02 & $\begin{array}{c}3.06 \times 10^{-10} \\
(\mathbf{3 . 0 0} \pm \mathbf{0 . 3 4}) \times \mathbf{1 0}^{-10}\end{array}$ \\
\hline \multirow[t]{3}{*}{ trans-2-pentenal } & $1.6-2.9$ & Ethane & $1.2-2.2$ & $\begin{array}{l}\mathrm{N}_{2}(3) \\
\text { Air (2) }\end{array}$ & $2.5-4.0$ & 2.08 & $1.22 \times 10^{-10}$ \\
\hline & $1.9-3.0$ & Propene & $1.9-3.0$ & $\begin{array}{l}\mathrm{N}_{2}(3) \\
\text { Air (3) }\end{array}$ & $2.5-4.0$ & 0.60 & $1.38 \times 10^{-10}$ \\
\hline & $1.9-3.0$ & 1-Butene & $1.9-3.0$ & $\begin{array}{l}\mathrm{N}_{2}(2) \\
\text { Air }(2)\end{array}$ & $2.3-3.8$ & 0.44 & $\begin{array}{c}1.32 \times 10^{-10} \\
(\mathbf{1 . 3 1} \pm \mathbf{0 . 1 9}) \times \mathbf{1 0}^{-10}\end{array}$ \\
\hline \multirow[t]{3}{*}{ trans-2-hexenal } & $1.6-2.9$ & Ethane & $1.2-2.2$ & $\begin{array}{l}\mathrm{N}_{2}(2) \\
\text { Air (2) }\end{array}$ & $2.5-4.0$ & 3.24 & $1.89 \times 10^{-10}$ \\
\hline & $1.9-3.0$ & Propene & $1.9-3.0$ & $\begin{array}{l}\mathrm{N}_{2}(2) \\
\text { Air (2) }\end{array}$ & $2.5-4.0$ & 0.84 & $1.94 \times 10^{-10}$ \\
\hline & $1.9-3.0$ & 1-Butene & $1.9-3.0$ & $\begin{array}{l}\mathrm{N}_{2}(2) \\
\text { Air (2) }\end{array}$ & $2.4-3.7$ & 0.65 & $\begin{array}{c}1.94 \times 10^{-10} \\
(\mathbf{1 . 9 2} \pm \mathbf{0 . 2 2}) \times \mathbf{1 0}^{-10}\end{array}$ \\
\hline \multirow[t]{3}{*}{ trans-2-heptenal } & $1.2-2.5$ & Ethane & $1.0-2.0$ & $\begin{array}{l}\mathrm{N}_{2}(3) \\
\text { Air (3) }\end{array}$ & $2.5-4.0$ & 4.48 & $2.62 \times 10^{-10}$ \\
\hline & $1.4-2.5$ & Propene & $1.4-2.5$ & $\begin{array}{l}\mathrm{N}_{2}(2) \\
\text { Air }(2)\end{array}$ & $2.5-3.9$ & 1.06 & $2.46 \times 10^{-10}$ \\
\hline & $1.4-2.5$ & 1-Butene & $1.4-2.5$ & $\begin{array}{l}\mathrm{N}_{2}(3) \\
\text { Air (3) }\end{array}$ & $2.2-3.8$ & 0.71 & $\begin{array}{c}2.13 \times 10^{-10} \\
(\mathbf{2 . 4 0} \pm \mathbf{0 . 2 9}) \times \mathbf{1 0}^{-10}\end{array}$ \\
\hline
\end{tabular}

\section{Experimental}

The rate constants were measured by following the simultaneous losses of the aldehyde and the different reference compounds (ethane, propene and 1-butene) during their reactions with chlorine atoms, using a $200 \mathrm{~L}$ Teflon reaction chamber with GC-FID detection. The arrangement of the apparatus and experimental procedures were described in detail previously, (Martínez et al., 2004), so only a brief description is given here. Relative rate experiments were carried out in air or $\mathrm{N}_{2}$ to check the potential interference from $\mathrm{OH}$ chemistry.

In the presence of atomic chlorine (molecular chlorine was photolyzed using a set of UV fluorescent lamps with a maximum intensity at $370 \mathrm{~nm}$ ), the corresponding aldehyde and reference compound decay via the following reactions:

$\mathrm{Cl}+$ Aldehyde $\rightarrow$ Products $\mathrm{k}_{\text {ald }}$

$\mathrm{Cl}+$ Reference $\rightarrow$ Products $\mathrm{k}_{\mathrm{ref}}$

If the reaction with $\mathrm{Cl}$ radicals is the only sink for the aldehyde and reference compounds, and no reactant is reformed in the process, it can be shown that

$\ln \left(\frac{[\text { aldehyde }]_{0}}{[\text { aldehyde }]_{t}}\right)=\frac{k_{\text {ald }}}{k_{\text {ref }}} \ln \left(\frac{[\text { reference }]_{0}}{[\text { reference }]_{t}}\right)$

where [aldehyde $]_{0}$ and $[\text { reference }]_{0}$ and [aldehyde $]_{t}$ and [reference $]_{t}$ are the concentrations of reactant and reference compound at time $\mathrm{t}=0$ and $\mathrm{t}$, respectively; and $\mathrm{k}_{\text {ald }}$ and $\mathrm{k}_{\text {ref }}$ 
are the rate constants of Reactions (1) and (2), respectively. Given an accurate value for the rate constant of the reference compound $\left(\mathrm{k}_{\mathrm{ref}}\right)$, the rate constant for the aldehyde $\left(\mathrm{k}_{\mathrm{ald}}\right)$ can be calculated immediately, i.e. $k_{\text {ald }}=($ slope $) k_{\text {ref }}$. The corresponding ranges of concentrations for the aldehydes, reference compounds, $\mathrm{Cl}$-atom source, etc. are given in Table 1.

The reaction chamber was manually agitated prior to the irradiation to ensure good mixing. The reagents were allowed to mix for $2 \mathrm{~h}$ before the first chromatogram was taken. The mixture was then photolysed. Total irradiation times ranged from 60 to $120 \mathrm{~min}$.

Aldehydes were expected to be lost by direct photolysis or adsorption in the smog chamber. For such reason, the carbonylic compounds were introduced alone in the reactor. Then the bag was irradiated using all fluorescent tubes for twice the duration of kinetic experiments to evaluate both photolysis and wall losses. No measurable changes were observed.

In additional experiment, reaction mixtures were sampled in the dark to test for potential losses of the aldehydes or reference compound by a dark reaction with $\mathrm{Cl}_{2}$, but no secondary reactions was observed under the experimental conditions.

The chemicals used were as follows: Synthetic Air (99.999\%, Air Liquide), $\mathrm{N}_{2}$ (99.998\%, Air Liquide), $\mathrm{Cl}_{2}$ (99.8\%, Praxair); ethane $(99+\%$, Aldrich), propene $(99+\%$, Aldrich), 1-butene (99+\%, Aldrich), trans-2-pentenal (95\%, Aldrich), trans-2-hexenal (98\%, Aldrich), trans-2-heptenal (98\%, Acros Organic), n-pentanal (97\%, Aldrich), n-hexanal (98\%, Aldrich) and n-heptanal (95\%, Aldrich) were further purified before use by repeated trap-to-trap distillation.

\section{Results and discussion}

Figure 1 shows the obtained relative loss of the aldehydes versus the reference compounds in the presence of $\mathrm{Cl}$ atoms at room temperature and atmospheric total pressure. Typically, a set of experiments was repeated on different days with a total of approximately $8-10$ runs. The plot of $\ln \left([\text { aldehyde }]_{0} /[\text { aldehyde }]_{t}\right)$ vs. $\ln \left([\text { reference }]_{0} /[\text { reference }]_{t}\right)$ yields a straight line with the slope of $\mathrm{k}_{\mathrm{ald}} / \mathrm{k}_{\mathrm{ref}}$, showing in all cases a good linearity which suggests that the extent of secondary reactions was negligible. The rate constants of the reactions of $\mathrm{Cl}$ with the compounds used as reference in this work were taken as, from reference Hitsuda et al. (2001) $(5.85 \pm 0.55) \times 10^{-11}$, Stutz et al. (1998) $(2.31 \pm 0.29) \times 10^{-10}$ and Orlando et al. (2003) $(3.00 \pm 0.40) \times 10^{-10}\left(\mathrm{~cm}^{3}\right.$ molecule $\left.{ }^{-1} \mathrm{~s}^{-1}\right)$ for ethane, propene and 1-butene, respectively. The slopes of such sets were calculated using a weighted linear leastsquares fit and the quoted errors in the final results are $2 \sigma$. The obtained results were independent to the bath gas used, air or $\mathrm{N}_{2}$ and so the reported kinetic rate constants are the average values, Table 1 .
No previous experimental rate constant values have been found for the reactions of the studied aldehydes with $\mathrm{Cl}$ atoms, except for n-pentanal (Thèvenet et al., 2000), n-hexanal and n-heptanal (Plagens, 2001). Our experimental result for $\mathrm{n}$-pentanal is in excellent agreement with the value reported by Thèvenet et al., $(2.6 \pm 0.3) \times 10^{-10} \mathrm{~cm}^{3}$ molecule $\mathrm{s}^{-1}$. These authors reported the average rate constant derived from the experiments with different reference compounds (ethane, propane, n-butane) and also using a relative technique. Plagens determined the coefficients for some alkyl aldehydes in a chamber, using the relative technique and FTIR for the analysis and 1,3-butadiene as the reference compound. The values obtained by Plagens for hexanal and heptanal $(3.23 \pm 0.15) \times 10^{-10}$ and $(3.53 \pm 0.10) \times 10^{-10}$ (in $\mathrm{cm}^{3}$ molecule $\mathrm{s}^{-1} \mathrm{~s}^{-1}$ ), respectively are around 12 and $18 \%$ higher than those reported for the same compounds in the present work but agree within the combined error limits of both determinations. Recent unpublished work in another laboratory (Cuevas et al., personal communication) using the absolute method of Laser Photolysis-Resonance Fluorescence (PLP-RF), has also demonstrated a $\mathrm{Cl}+\mathrm{n}$-pentanal rate constant that is $27 \%$ lower than that reported by Thevenet et al. (2000) at room temperature, but that is consistent with the findings of this present study.

From the analysis of the data given in Table 1, reaction rate constants are of the order of $10^{-10} \mathrm{~cm}^{3}$ molecule ${ }^{-1} \mathrm{~s}^{-1}$ and they increase when the length of the organic chain increases in both saturated and unsaturated aldehydes,

$k_{\mathrm{n}-\text { pentanal }}<k_{\mathrm{n}-\text { hexanal }}<k_{\mathrm{n}-\text { heptanal }}$
$k_{\text {trans-2-pentenal }}<k_{\text {trans-2-hexenal }}<k_{\text {trans-2-heptenal }}$

A similar behavior, the increase of the rate constant value with the number of methylene groups, was also found in the reactions of $\mathrm{Cl}$ atoms with alkanes (Wallington et al., 1988; Hooshiyar and Niki, 1995; Qian et al., 2001).

On the other hand, in Table 2, the rate constants for the reactions of $\mathrm{Cl}$ radicals with the studied aldehydes and with similar structured alkanes and alkenes are given for comparison. The constants for the reaction of $\mathrm{Cl}$ with saturated aldehydes, are similar to the values for the reaction of $\mathrm{Cl}$ with saturated alkanes (Hooshiyar and Niki, 1995; Qian et al., 2001). However, the obtained coefficients for $\alpha, \beta$-unsaturated aldehydes with $\mathrm{Cl}$ are smaller than the rate constants for the reaction of $\mathrm{Cl}$ with the saturated aldehydes and the reference alkenes (see Table 2). In this sense, reactivity ratios of 0.43 and 0.40 may be calculated for $\mathrm{Cl}$ trans-2-pentenal/1-butene and trans-2-hexenal/1pentene, respectively. In the case of the trans-2-heptenal/1hexene reactivity ratio, no data about the rate constant has been found for the reaction of 1-hexene with $\mathrm{Cl}$ atoms. Nevertheless, on the basis of the increase of the reactivity of the series $\mathrm{Cl}+$ propene, $\mathrm{Cl}+1$-butene and $\mathrm{Cl}+1$-pentene, $(2.31 \pm 0.29) \times 10^{-10},(3.00 \pm 0.40) \times 10^{-10}$ and $4.83 \times 10^{-10}$ 

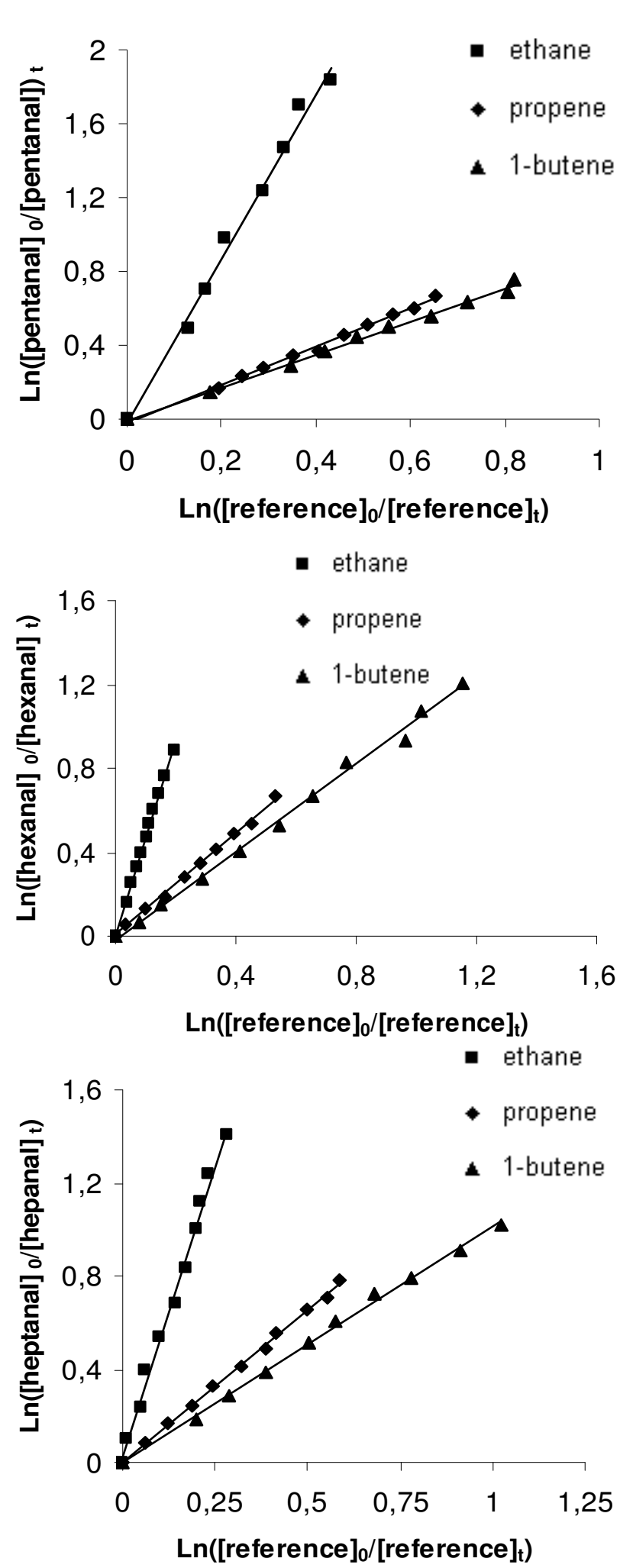
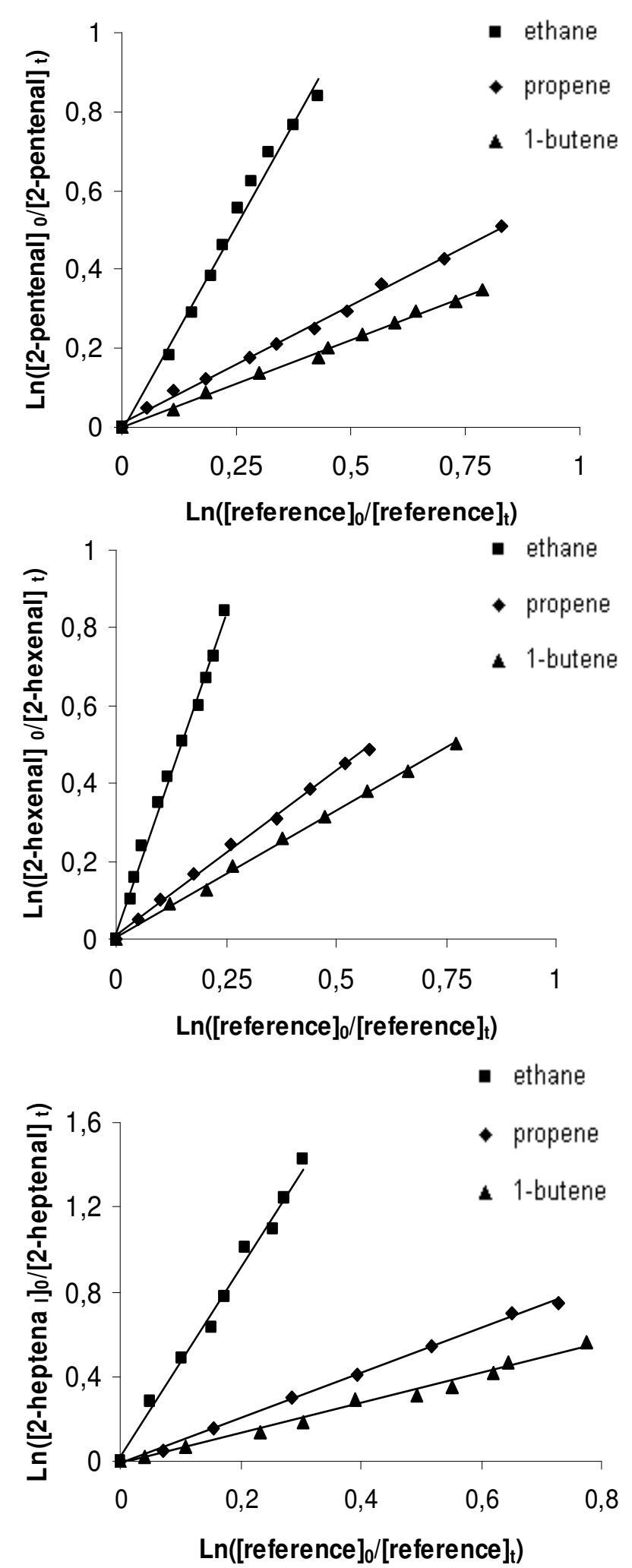

Fig. 1. Decays of aldehydes vs. reference compounds in the presence of $\mathrm{Cl}$ atoms at room temperature and atmospheric total pressure of $\mathrm{N}_{2}$ or Air. 
Table 2. Room temperature rate constants of $\mathrm{Cl}$ with aldehydes and with the corresponding alkanes or alkenes at room temperature. $\mathrm{k}_{\mathrm{alkane}}$ or $\mathrm{k}_{\text {alkene }}$ and $\mathrm{k}_{\text {aldehyde }}$ are in units of $\mathrm{cm}^{3}$ molecule ${ }^{-1} \mathrm{~s}^{-1}$.

\begin{tabular}{ccc}
\hline Alkane, $\mathrm{k}_{\text {alkane }}$ Alkene, $\mathrm{k}_{\text {alkene }}$ & Aldehyde, $\mathrm{k}_{\text {aldehyde }}$ & $\mathrm{k}_{\text {aldehyde }} / \mathrm{k}_{\text {alkane }} \mathrm{k}_{\text {aldehyde }} / \mathrm{k}_{\text {alkene }}$ \\
\hline butane, $2.15 \times 10^{-10 \mathrm{a}}$ & n-pentanal, $2.56 \times 10^{-10 \mathrm{~b}}$ & 1.19 \\
Pentane, $2.5 \times 10^{-10 \mathrm{c}}$ & n-hexanal, $2.88 \times 10^{-10 \mathrm{~b}}$ & 1.15 \\
hexane, $3.06 \times 10^{-10 \mathrm{c}}$ & n-heptanal, $3.00 \times 10^{-10 \mathrm{~b}}$ & 0.98 \\
1-butene, $3.00 \times 10^{-10 \mathrm{~d}}$ & trans-2-pentenal, $1.31 \times 10^{-10 \mathrm{~b}}$ & 0.43 \\
1-pentene, $4.83 \times 10^{-10 \mathrm{e}}$ & trans-2-hexenal, $1.92 \times 10^{-10 \mathrm{~b}}$ & 0.40 \\
1-hexene, $>4.83 \times 10^{-10 \mathrm{f}}$ & trans-2-heptenal, $2.40 \times 10^{-10 \mathrm{~b}}$ & $<0.49^{\mathrm{f}}$ \\
\hline
\end{tabular}

${ }^{\mathrm{a}}$ Tyndall et al. (1997); ${ }^{\mathrm{b}}$ This work; ${ }^{\mathrm{c}}$ Hooshiyar et al. (1995); ${ }^{\mathrm{d}}$ Orlando et al. (2003); ${ }^{\mathrm{e}}$ Coquet et al. $(2000) ;{ }^{\mathrm{f}}$ See Text.

$\left(\mathrm{cm}^{3}\right.$ molecule $\left.{ }^{-1} \mathrm{~s}^{-1}\right)$, respectively, one can assume a reactivity ratio trans-2-heptenal/1-hexene $<0.5$ which is similar to the other two unsaturated aldehydes, in light of the probable value for the $\mathrm{Cl}+1$-hexene constant, $>4.83 \times 10^{-10} \mathrm{~cm}^{3}$ molecule ${ }^{-1} \mathrm{~s}^{-1}$.

The deactivation effects observed in this work for aldehydes is smaller than those found for reactions of ketones (both saturated and unsaturated) and the corresponding alkanes with $\mathrm{Cl}$ atoms (Albaladejo et al., 2003). The reason may reside in the fact that the $\mathrm{CHO}$ group is a reactive site itself (and so it contributes to the global rate constant) while reactions on the $\mathrm{CO}$ group are not expected.

The previous observations may be explained if we take into account the reaction mechanism. The observed mechanism for the reactions of $\mathrm{NO}_{3}$ radical with aldehydes proceeds by $\mathrm{H}$-atom abstraction from the $\mathrm{CHO}$ group (Atkinson and Arey, 2003). OH reactions with formaldehyde, acetaldehyde and propanal are considered to proceed also exclusively by $\mathrm{H}$-atom abstraction from the $\mathrm{CHO}$ group although contributions to the rate constants are expected from other $\mathrm{CH}$ bonds for higher aldehydes (Atkinson and Arey, 2003).

The results obtained in this work may by justified by the higher reactivity of $\mathrm{Cl}$ atoms compared to $\mathrm{NO}_{3}$ and $\mathrm{OH}$ radicals, (approximately four and one order of magnitude, respectively, Table 3 ). $\mathrm{Cl}$ atoms are much more reactive and thus less selective than $\mathrm{NO}_{3}$ and even $\mathrm{OH}$ radicals. In this sense, $\mathrm{H}$-atom transfer from the alkyl groups is much faster with $\mathrm{Cl}$ than with $\mathrm{NO}_{3}$ or $\mathrm{OH}$. So, the $\mathrm{CHO}$ group is no longer the exclusive site of reaction. The rate constants of the related alkanes are similar to those of the aldehydes, Table 2, indicating that the contribution of $\mathrm{CH}$ bonds (other than $\mathrm{CHO}$ ) to the global rate constant must be important. This was also observed even for shorter aliphatic aldehydes like acetaldehyde and propanal (Thevenet et al., 2000). In the case of propanal, Structure-Activity Relationships based calculations predicted the aliphatic chain as the dominant reaction site (Thevenet et al., 2000). Nevertheless, for the relatively large saturated aldehydes studied in this work, the increase of the rate constant with the number of $\mathrm{CH}_{2}$ groups is slight and it may not be exclusively due to the increase of the number of reactive sites. The kinetic rate constants are so high that reactions are becoming limited by the collision frequency (which also increases with the size of the molecule) rather than by the reaction itself.

With respect to the series of unsaturated aldehydes, these compounds have an additional reactive site, the double bond. The addition mechanism may even be predominant for $\mathrm{Cl}-$ alkenes reactions at atmospheric pressure and room temperature (Lee and Rowland, 1977). So an increase of reactivity from the alkene or the saturated aldehyde was expected but was not observed.

The conjugation of the double bond with the carbonylic group could be responsible for the decrease of reactivity when both groups are found together. First, the presence of the double bond involves the substitution of two $\mathrm{CH}_{2}$ groups by $\mathrm{CH}=\mathrm{CH}$. These hydrogen atoms are linked to " $\mathrm{sp}^{2}$ " hybridized carbon atoms with bonds of higher energy dissociation and so less susceptible to abstraction. Second, the conjugation with the carbonylic group significantly reduces the partial negative charge on the $\beta$ carbon atom and thus the electrophylic addition is inhibited in that position compared to the reference alkene. In this sense the addition mechanism is expected to occur only (mainly) on the $\alpha$ carbon atom. Semi-empirical PM3 calculations were performed within the MOPAC package to obtain the partial charge on the $\beta$ carbon atoms, giving similar results for the three studied unsaturated aldehydes, $-0.125 \pm 0.001$ while the partial charge on the same carbon atom of the equivalent alkene was clearly higher, $0.204 \pm 0.001$.

Concerning the atmospheric implications of the studied $\mathrm{Cl}$ atoms reactions, the results are compared with the reactivity with $\mathrm{O}_{3}, \mathrm{OH}$ and $\mathrm{NO}_{3}$ radicals in Table 3 . The rate constants summarised in the table can be used to calculate the atmospheric lifetimes expressed in hours $(\tau=1 / k[\mathrm{X}]$, where $\mathrm{X}=\mathrm{Cl}, \mathrm{OH}, \mathrm{NO}_{3}$ or $\mathrm{O}_{3}$ ) using the average global concentrations: $[\mathrm{Cl}]=10^{3}-10^{4}$ (Pszenny et al., 1993; Wingenter et al., 1996), $[\mathrm{OH}]=5.0 \times 10^{5}$ (Brauers et al., 1996), $\left[\mathrm{NO}_{3}\right]=7.4 \times 10^{6}($ Noxon, 1983$)$ and $\left[\mathrm{O}_{3}\right]=7.4 \times 10^{11}($ Logan, 1985) (in units of molecule $\mathrm{cm}^{-3}$ ). 
Table 3. Summary of the rate coefficients for $\mathrm{OH}, \mathrm{NO}_{3}, \mathrm{O}_{3}$ and $\mathrm{Cl}$ reaction with the aldehydes studied in this work (in $\mathrm{cm}^{3}$ molecule $\mathrm{m}^{-1} \mathrm{~s}^{-1}$ ) and atmospheric lifetimes, $\tau$ (in hours).

a: This work;

b: Albaladejo et al. (2002).

c: Cabañas et al. (2001b).

d: Cabañas et al. (2001a).

e: Grosjean et al. (1996).

$[\mathrm{Cl}]=5 \times 10^{3}$ molecule $\mathrm{cm}^{-3}$ (Pszenny et al., 1993; Wingenter et al., 1996), $[\mathrm{OH}]=5.0 \times 10^{5}$ molecule $\mathrm{cm}^{-3}$ (Brauers et al., 1996) and $\left[\mathrm{NO}_{3}\right]=7.4 \times 10^{6}$ molecule $\mathrm{cm}^{-3}$ (Noxon, 1983), $\left[\mathrm{O}_{3}\right]=7.4 \times 10^{11}$ molecule $\mathrm{cm}^{-3}$ (Logan, 1985).

\begin{tabular}{ccccccccc}
\hline Aldehyde & $\mathrm{k}_{\mathrm{Cl} \times 10^{10 \mathrm{a}}}$ & $\tau_{\mathrm{Cl}}$ & $\mathrm{k}_{\mathrm{OH}} \times 10^{11 \mathrm{~b}}$ & $\tau_{\mathrm{OH}}$ & $\mathrm{k}_{\mathrm{NO} 3} \times 10^{14}$ & $\tau_{\mathrm{NO} 3}$ & $\mathrm{k}_{\mathrm{O} 3 \times 10^{18} \mathrm{e}} \tau_{\mathrm{O} 3}$ \\
\hline $\mathrm{CH}_{3}\left(\mathrm{CH}_{2}\right)_{3} \mathrm{CHO}$ & $2.56 \pm 0.27$ & 217 & $2.48 \pm 0.24$ & 22.4 & $1.75 \pm 0.16^{\mathrm{c}}$ & 2145 & - & - \\
$\mathrm{CH}_{3}\left(\mathrm{CH}_{2}\right)_{4} \mathrm{CHO}$ & $2.88 \pm 0.37$ & 192.9 & $2.60 \pm 0.21$ & 21.4 & $1.83 \pm 0.36^{\mathrm{c}}$ & 2051 & - & - \\
$\mathrm{CH}_{3}\left(\mathrm{CH}_{2}\right)_{5} \mathrm{CHO}$ & $3.00 \pm 0.34$ & 185.2 & $2.96 \pm 0.23$ & 18.8 & $2.37 \pm 0.42^{\mathrm{c}}$ & 1584 & - & - \\
$\mathrm{CH}_{3} \mathrm{CH}_{2} \mathrm{CH}=\mathrm{CHCHO}$ & $1.31 \pm 0.19$ & 424.1 & $2.35 \pm 0.32$ & 23.6 & $2.88 \pm 0.29^{\mathrm{d}}$ & 1303 & - & - \\
$\mathrm{CH}_{3}\left(\mathrm{CH}_{2}\right)_{2} \mathrm{CH}=\mathrm{CHCHO}$ & $1.92 \pm 0.22$ & 289.3 & $2.95 \pm 0.45$ & 18.8 & $5.49 \pm 0.95^{\mathrm{d}}$ & 684 & $1.28 \pm 0.28$ & 293 \\
$\mathrm{CH}_{3}\left(\mathrm{CH}_{2}\right)_{3} \mathrm{CH}=\mathrm{CHCHO}$ & $2.40 \pm 0.29$ & 231.5 & $2.45 \pm 0.30$ & 22.7 & $9.59 \pm 0.19^{\mathrm{d}}$ & 391 & - & - \\
\hline
\end{tabular}

Furthermore, Martínez et al. (1992) and Plagens have reported the absorption spectra of several aliphatic and unsaturated aldehydes and ketones. These compounds absorb actinic radiation in the range $270-340 \mathrm{~nm}$ and so the estimates about the degradation under atmospheric conditions must include the photolysis contribution. In this sense, Plagens reports photolytic lifetimes of 15 and 10 hour for hexanal and trans-2-hexenal, respectively. These data suggest that photodissociation and gas-phase reactions with $\mathrm{OH}$ radicals will dominate over reactions with $\mathrm{Cl}$ atoms and $\mathrm{NO}_{3}$.

Although the reactions of chlorine atoms with this series of aldehydes are very fast, the average measured $\mathrm{Cl}$ concentration is lower than the concentrations of other oxidants. For this reason, the aldehydes lifetime is in the order of 200$400 \mathrm{~h}$, which is comparable to the lifetimes due to $\mathrm{O}_{3}$ with trans-2-hexenal (only the trans-2-hexenal has been studied (Grosjean et al., 1996). Nevertheless, the contribution of $\mathrm{Cl}$ atoms may be significant in those areas with higher concentrations. If we assume that the $\mathrm{Cl}$ local peak concentrations may be as high as $10^{5}$ atom $\mathrm{cm}^{-3}$ (Wingenter et al., 1996; Singh et al., 1996), then these lifetimes are around between twice and one hundred times lower than those with respect to reaction with $\mathrm{OH}$ and $\mathrm{NO}_{3}$, respectively. So chlorine atoms reactions are expected to play a significant role in the degradation of the studied aldehydes at dawn in the marine boundary layer and in coastal areas. That may be also the case of some urban contaminated areas, where high levels of chlorine may originate from industrial emissions (Galan et al., 2002). In this sense, regional-scale photochemical modeling and ambient observations in southeastern Texas suggest that chlorine radical chemistry enhances ozone formation (Chang et al., 2002). The ozone enhancement demonstrated strong spatial and temporal variations. Maximum enhancement occurred in the mornings in the industrialized areas and was pri- marily associated with estimated emissions of chlorine from cooling towers. A secondary maximum in the late afternoon was observed in the urban area and was associated with estimated emissions from swimming pools (Chang et al., 2002).

In the case of heterogeneous processes, it is well known that alcohols, aldehydes and ketones undergo efficient uptake into cloud droplets (Jayne et al., 1992) where chemical transformation can occur. For example, aldehydes can react with aqueous $\mathrm{SO}_{2}$ to form the complex hydroxymethanesulfonate. In this sense, field studies have measured organic species in cloud droplets and carbonyl species have been detected in the snowpack (Sumner and Shepson, 1999). Also recently, several authors have investigated the involvement of aldehydic compounds in the formation of oligomeric components in secondary organic aerosols (Gao et al., 2004; Kalberer et al., 2004; Jang et al., 2002). The distinct effects of carbon numbers, substituent groups, and isomeric structures of the precursor hydrocarbons on the composition and yield of secondary organic aerosols formed are also discussed, for example, by Gao et al. (2004). Thus, further studies are required to evaluate the contribution of heterogeneous processes to the atmospheric degradation of aldehydes.

Acknowledgements. We thank the financial support from the Spanish MCyT (BQU 2001-157-4 and CGL 2004-03355 projects), Junta de Comunidades de Castilla La Mancha (PAI-02-008 project) and Universidad de Castilla La Mancha (0111001329-541 A project).

Edited by: W. T. Sturges 


\section{References}

Albaladejo J., Ballesteros B., Jiménez E., Martín P., and Martínez, E.: A PLP-LIF kinetic study of the atmospheric reactivity of a series of $\mathrm{C}_{4}-\mathrm{C}_{7}$ saturated and unsaturated aliphatic aldehydes with OH, Atmos. Environ., 36, 3231-3239, 2002.

Albaladejo, J., Notario, A., Cuevas, C. A., Jiménez, E., Cabañas, B., and Martínez, E.: Gas-phase chemistry of atmospheric $\mathrm{Cl}$ atoms: a PLP-RF kinetic study with a series of ketones, Atmos. Environ., 37, 455-463, 2003.

Atkinson, R. and Arey, J.: Atmospheric Degradation of Volatile Organic Compounds, Chem. Rev., 103, 4605-4638, 2003.

Brauers, T., Aschmutat, U., Brandenburger, U., Dorn, H. P., Hausmann, M., Hessling, M., Hofzumahaus, A., Holland, F., PlasDulmer, C., and Ehhalt, D. H.: Intercomparison of Tropospheric $\mathrm{OH}$ Radical Measurements by Multiple Folded LongPath Laser Absorption and Laser Induced Fluorescence, Geophys. Res. Lett., 23, 2545-2548, 1996.

Cabañas, B., Salgado, S., Martín, P., Baeza, M. T., and Martínez, E.: Night-time atmospheric loss process for unsaturated aldehydes: Reaction with $\mathrm{NO}_{3}$ radicals, J. Phys. Chem. A., 105, 4440-4445, 2001a.

Cabañas, B., Martín, P., Salgado, S., Ballesteros, B., and Martínez, E.: An experimental study on the temperature dependence for the gas-phase reactions of $\mathrm{NO}_{3}$ radical with a series of aliphatic aldehydes, J. Atmos. Chem., 40, 23-39, 2001b.

Chang, S. Y., McDonald-Buller, E., Kimura, Y., Yarwood, G., Neece, J., Russell, M., Tanaka, P., and Allen, D.: Sensitivity of urban ozone formation to chlorine emission estimates, Atmos. Environ., 36, 4991-5003, 2002.

Coquet S. and Ariya, P. A.: Kinetics of the gas-phase reactions of $\mathrm{Cl}$ atom with selected $\mathrm{C}_{2}-\mathrm{C}_{5}$ unsaturated hydrocarbons at $283<\mathrm{T}<323$ K, Int. J. Chem. Kinet., 32, 478-484, 2000.

Galan, E., Gonzalez, I., and Fabbri, B.: Estimation of fluorine and chlorine emissions from Spanish structural ceramic industries. The case study of the Bailen area, Southern Spain, Atmos. Environ., 36, 5289-5298, 2002.

Gao, S., Keywood, M., Ng, N. L., Surratt, J., Varutbangkul, V., Bahreini, R., Flagan, R. C., and Seinfeld, J. H.: LowMolecular-Weight and Oligomeric Components in Secondary Organic Aerosol from the Ozonolysis of Cycloalkenes and $\alpha$ Pinene, J. Phys. Chem., 108, 10 147-10 164, 2004.

Grosjean, D., Grosjean, E., and Gertler, A. W.: On-road emissions of carbonyls from light-duty and heavy-duty vehicles, Environ. Sci. Technol., 35, 45-53, 2001.

Grosjean, E., Grosjean, D., and Seinfeld, J. H.: Gas-phase reaction of ozone with trans-2-hexenal, trans-2-hexenyl acetate, ethylvinyl ketone, and 6-methyl-5-hepten-2-one, Int. J. Chem. Kinet., 28, 373-382, 1996.

Hitsuda, K., Takahashi, K., Matsumi, Y., and Wallington, T. J.: Kinetics of the reactions of $\mathrm{Cl}(\mathrm{P}-2(1 / 2))$ and $\mathrm{Cl}(\mathrm{P}-2(3 / 2))$ atoms with $\mathrm{C}_{2} \mathrm{H}_{6}, \mathrm{C}_{2} \mathrm{D}_{6}, \mathrm{CH}_{3} \mathrm{~F}, \mathrm{C}_{2} \mathrm{H}_{5} \mathrm{~F}$, and $\mathrm{CH}_{3} \mathrm{CF}_{3}$ at $298 \mathrm{~K}$, J. Phys. Chem. A., 105, 5131-5136, 2001.

Hooshiyar, P. A., and Niki, H.: Rate constants for the gas-phase reactions of $\mathrm{Cl}$-atoms with $\mathrm{C}_{2}-\mathrm{C}_{8}$ alkanes at $\mathrm{T}=296+/-2 \mathrm{~K}$, Int. J. Chem. Kinet., 27, 1197-1206, 1995.

Jang, M., Czoschke, N. M., Lee, S., and Kamens, R. M.: Heterogeneous Atmospheric Aerosol Production by Acid-Catalyzed Particle-Phase Reactions, Science, 298, 814-817, 2002.

Jayne, J. T., Duan, S. X., Davidovits, P., Worsnop, D. R., Zahniser,
M. S., and Kolb, C. E.: Uptake of gas-phase aldehydes by water surfaces, J. Phys. Chem., 96, 5452-5460, 1992.

Kalberer, M., Paulsen, D., Sax, M., Steinbacher, M., Dommen, J., Prevot, A. S. H., Fisseha, R., Weingartner, E., Frankevich, V., Zenobi, R., and Baltensperger, U.: Identification of Polymers as Major Components of Atmospheric Organic Aerosols, Science, 303, 1659-1662, 2004.

Lee, F. S. C. and Rowland, F. S.: Reaction of chlorine atoms with acetylene and its possible stratospheric significance, J. Phys. Chem., 81, 684-685, 1977.

Logan, J. A.: Tropospheric Ozone-Seasonal Behavior, Trends and Anthropogenic Influence, J. Geophys. Res.-Atmospheres, 90, Nd6, 463-482, 1985.

Martinez, R. D., Buitrago, A. A., Howell, N. W., Hearn, C. H., and Joens, F.: The near U.V. absorption spectra of several aliphatic aldehydes and ketones at $300 \mathrm{~K}$, Atmos. Environ., 26, 785-792, 1992.

Martínez, E., Aranda, A., Diaz-De-Mera, Y., Rodríguez, A, Rodríguez, D., and Notario, A.: Mechanistic and kinetic study of the gas-phase reaction of atomic chlorine with cyclohexanone using an absolute and a relative technique, Influence of temperature, J. Atmos. Chem., 48, 283-299, 2004.

Noxon, J. F.: $\mathrm{NO}_{3}$ and $\mathrm{NO}_{2}$ in the Mid-Pacific Troposphere, J. Geophys. Res.-Oceans and Atmospheres, 88, NC15, 1017-1021, 1983.

Orlando, J. J., Tyndall, G. S., Apel, E. C., Riemer, D., and Paulson, S. E.: Rate coefficients and mechanisms of the reaction of $\mathrm{Cl}$-atoms with a series of unsaturated hydrocarbons under atmospheric conditions, Int. J. Chem. Kinet., 35, 334-353, 2003.

Papagni, C., Arey, J., and Atkinson, R.: Rate constants for the gasphase reactions of a series of $\mathrm{C}_{3}-\mathrm{C}_{6}$ aldehydes with $\mathrm{OH}$ and $\mathrm{NO}_{3}$ radicals, Int. J. Chem. Kinet., 32, 79-84, 2000.

Plagens, H.: Untersuchugen zum atmosphärenchemischen Abbau langkettiger Aldehyde, PhD thesis, Germany, 2001.

Prates, H. T., Leite, R. C., Craveiro, A. A., and Oliveira, A. B.: Identification of some chemical components of the essential oil from molasses grass (Melinis minutiflora Beauv.) and their activity against cattle-tick (Boophilus microplus), Journal of the Brazilian Chemical Society 9, 993-197, 1998.

Pszenny, A. A. P., Keene, W. C., Jacob, D. J., Fan, S., Maben, J. R., Zetwo, M. P., Springer-Young, M., and Galloway, J. N.: Evidence Of Inorganic Chlorine Gases Other Than HydrogenChloride In Marine Surface Air, Geophys. Res. Lett., 20, 699, 1993.

Qian, H. B., Turton, D., Seakins, P. W., and Pilling, M. J.: Laser flash photolysis/IR diode laser absorption study of the reaction of chlorine atoms with selected alkanes, Int. J. Chem. Kinet., 34, 86-94, 2001.

Singh, H. B., Thakur, A. N., and Chen, Y. E.: Tetrachloroethylene as an indicator of low $\mathrm{Cl}$ atom concentrations in the troposphere, Geophys. Res. Lett., 23, 1529-1532, 1996.

Spicer, C. W., Chapman, E. G., Finlayson-Pitts, B. J., Plastridge, R. A , Hubbe, J. M., Fast, J. D., and Berkowitz, C. M.: Unexpectedly high concentrations of molecular chlorine in coastal air, Nature, 394, 353-356, 1998.

Stutz, J., Ezell, M. J., Ezell, A. A., and Finlayson-Pitts, B. J.: Rate constants and kinetic isotope effects in the reactions of atomic chlorine with n-butane and simple alkenes at room temperature, J. Phys. Chem., 102, 8510-8519, 1998. 
Sumner, A. L. and Shepson, P. B.: Snowpack production of formaldehyde and its effect on the Arctic troposphere, Nature, 398, 230-233, 1999.

Thèvenet, R., Mellouki, A., Le Bras, G.: Kinetics of $\mathrm{OH}$ and $\mathrm{Cl}$ reactions with a series of aldehydes, Int. J. Chem. Kinet., 32, 676-685, 2000.

Tyndall, G. S., Orlando, J. J., Wallington, T. J., Dill, M., and Kaiser, E. W.: Kinetics and mechanisms of the reactions of chlorine atoms with ethane, propane, and n-butane, Int. J. Chem. Kinet., 29, 43-55, 1997.
Wallington, T. J., Skewes, L. M., Siegl, W. O., Wu, C. H., and Japar, S. M.: Gas-phase reaction of $\mathrm{Cl}$ atoms with a series of oxygenated organic-species at 295-K, Int. J. Chem. Kinet., 20, 867-875, 1988 .

Wingenter, O. W., Kubo, M. K., Blake, N. J., Smith, T. W., Blake, D. R., and Rowland, F. S.: Hydrocarbon and halocarbon measurements as photochemical and dynamical indicators of atmospheric hydroxyl, atomic chlorine, and vertical mixing obtained during Lagrangian flights, J. Geophys. Res., 101, 4331-4340, 1996. 